\title{
Membangun Kesadaran Global Warga Negara: Studi Kebijakan Publik Di Era Pandemi Covid 19
}

\section{Building Citizen Global Awareness: Public Policy Studies in the Covid 19 Pandemic Era}

\author{
Surya Dharma* \\ Jurusan Pendidikan Pancasila dan Kewarganegaraan, Fakultas Ilmu Sosial, \\ Universitas Negeri Medan, Indonesia
}

Diterima: 27 Desember 2020; Disetujui: 5 Januari 2021; Dipublish: 31 Januari 2021

\begin{abstract}
Abstrak
Saat ini dunia sedang dihadapkan dengan berbagai masalah global yang mempengaruhi kehidupan warga negara baik di tingkat lokal maupun nasional. Misalnya saja bagaimana pemanasan global mempengaruhi pertanian masyarakat di pedesaan. Pembakaran hutan yang terjadi di suatu wilayah menyebabkan udara buruk di wilayah lain bahkan melintasi antar negara. Begitu juga dengan pandemi virus covid-19 yang mempengaruhi kesehatan masyarakat secara global. Berbagai masalah global ini hanya dapat diselesaikan secara kolaboratif dengan melibatkan semua pihak. Sebagai warga negara perlu adanya kesadaran akan pentingnya sikap peduli, empati serta solidaritas yang tinggi terhadap berbagai masalah global. Keseluruhan sikap ini tercermin dalam perilaku yang menunjukkan ketaatan terhadap berbagai kebijakan yang dikeluarkan oleh pemerintah sebagai upaya dalam mencegah serta menyelesaikan berbagai masalah global. Tulisan ini bertujuan untuk mengidentifikasi, memetakan serta menganalisis berbagai wacana akademik dari studi empiris mengenai relevansi antara kebijakan publik di era Pandemi Covid-19 terhadap kesadaran global warga negara. Metode yang digunakan adalah dengan studi literatur. Hasilnya menunjukkan sebuah sintesa bahwa partisipasi warga negara terhadap berbagai kebijakan terkait pencegahan dan penanganan virus covid-19 sangat tergantung dari kesadaran masyarakat sebagai bagian dari masyarakat global.
\end{abstract}

Kata Kunci : Kesadaran Global; Kebijakan Publik; Covid-19

\begin{abstract}
Currently the world is faced with various global problems that affect the lives of citizens both at the local and national levels. For example, how global warming affects rural agriculture. Forest burning that occurs in one area causes bad air in other areas and even crosses between countries. Likewise with the covid-19 virus pandemic which affects public health globally. These global problems can only be resolved collaboratively by involving all parties. As citizens, it is necessary to have awareness of the importance of caring, empathy and high solidarity with various global problems. This overall attitude is reflected in behavior that shows adherence to various policies issued by the government in an effort to prevent and resolve various global problems. This paper aims to identify, map and analyze various academic discourses from empirical studies regarding the relevance of public policies in the Covid-19 Pandemic era to the global awareness of citizens. The method used is literature study. The results show a synthesis that citizen participation in various policies related to the prevention and handling of the Covid-19 virus is highly dependent on public awareness as part of the global community.

Keywords: Global Awareness; Public Policy; Covid-19
\end{abstract}

How to Cite: Dharma, S. (2021). Membangun Kesadaran Global Warga Negara: Studi Kebijakan Publik Di Era Pandemi Covid 19. PERSPEKTIF, 10 (1): 248-254

\begin{tabular}{lr}
\hline *Corresponding author: & ISSN 2085-0328 (Print) \\
E-mail: suryappkn@unimed.ac.id & ISSN 2684-9305(Online)
\end{tabular}




\section{PENDAHULUAN}

Pandemi Covid 19 merupakan salah satu dari sekian banyak masalah global yang mempengaruhi kehidupan warga negara di seluruh dunia. Dampaknya mempengaruhi segala aspek kehidupan baik sosial budaya, ekonomi, politik dan aspek lainnya. Data yang dirilis dari worldometers menyebutkan bahwa virus ini telah merenggut 1.749.340 korban jiwa di seluruh dunia, dengan kasus terinfeksi sebesar 79.729.121 pertanggal 25 Desember 2020

(https://www.worldometers.info/coronavirus) . Jumlah kasus ini akan terus bertambah seiring belum tersebarnya secara luas vaksin yang dapat digunakan oleh masyarakat di seluruh dunia. Untuk mencegah terjadinya dampak yang lebih parah, maka setiap negara mengeluarkan berbagai kebijakan sebagai upaya untuk menekan penyebaran virus. Berbagai kebijakan tersebut merupakan upaya preventif agar setiap orang dapat terhindar dari penularan. Beberapa kebijakan tersebut seperti melaksanakan pembelajaran secara daring (online), mengurangi aktivitas di luar rumah, membatasi terjadinya kerumunan, membatasi jam buka atau menutup beberapa tempat keramaian, menggunakan masker, serta berbagai aturan lainnya. Berbagai upaya ini diharapkan dapat mencegah terjadinya penularan virus yang lebih luas.

Akan tetapi pada realitanya tidak jarang masyarakat kurang menyadari dampak yang ditimbulkan dari pandemi covid-19 yang terjadi. Sebagian masyakat kurang menyadari pentingnya menjaga jarak sebagai upaya pencegahan dari penularan virus. Untuk mengantispasi hal tersebut, Indonesia sebagai salah satu dari negara yang terkena dampak dari Covid-19 melakukan berbagai strategi nasional. Sepertihalnya melakukan Pembatasan Sosial Berskala Besar (PSBB) yang bertujuan membatasi segala kegiatan ekonomi dan sosial di masyarakat. Selain itu pemerintah Indonesia juga menerapkan kebijakan pada masyarakat untuk tetap dirumah serta menjaga jarak pada 2 Provinsi serta 22 Kabupaten Kota di Indonesia (Kunjana, 2020). Kebijakan ini tentunya memberi dampak terhadap kehidupan masyarkat. Dalam konteks makro upaya pembatasan sosial akan menghentikan rantai pasokan global yang berakibat buruk pada perekonomian global. (Ebrahim, Ahmad, Gozzer, Schlagenhauf, \& Memish, 2020).
Sedangkan dalam konteks mikro Covid-19 memberi dampak psikologis dimana orangorang menjadi panik, tidak aman secara emosional, tertekan dan dalam tahap kebingungan (Singh, Agrawal, Sharma, \& Sharma, 2020; Harlianty, Widyastuti, Muhkhlis, \& Susanti, 2020). Langkah ini diharapkan dapat mengurangi terjadinya penularan virus yang mengancam banyak orang.

Berbagai kebijakan dilakukan sebagai upaya pencegahan dan penyebaran virus covid19. Akan tetapi upaya ini masih belum maksimal dalam memutus mata rantai penyebaran virus di Indonesia. Data yang diperoleh dari Satgas Penanganan Covid (2020) memperlihatkan kematian akibat virus ini pada tanggal 28 Desember 2020 mencapai 21.425 dengan jumlah kasus positif sebesar 719.219. Dengan kondisi tersebut Indonesia merupakan negara dengan kasus covid-19 tertinggi di Asia Tenggara (Kompas, 2020). Jumlah kasus positif akan terus bertambah jika masyarakat kurang menyadari bahaya yang diakibatkan dari virus covid-19. Rendahnya kesadaran masyarakat tidak terlepas dari upaya penegakan hukum yang dianggap masih belum memberikan efek jera bagi pelanggar protokol kesehatan yang sudah ditetapkan baik pemerintah pusat maupun daerah. Hasil penelitian yang dilakukan oleh (Adlin \& Yusri (2020) menyebutkan bahwa salah satu faktor yang menyebabkan rendahnya kesadaran masyarakat terhadap upaya penanganan covid dikarenakan sanksi yang kurang tegas. Sanksi yang dianggap kurang tegas ini mengakibatkan sebagian orang enggan memakai masker, menjaga jarak serta mencuci tangan.

Walaupun tidak sedikit masyarakat yang telah menyadari dampak dari virus ini sehingga berusaha mematuhi protokol kesehatan. Survey yang dilakukan oleh AC Nielsen yang bekerja sama dengan lembaga UNICEF, meneliti kepada 2.000 responden di 6 kota besar di Indonesia terkait perilaku masyarakat yang berhubungan dengan upaya pencegahan Covid 19. Hasil survey menunjukkan bahwa $31,5 \%$ dari responden melakukan seluruh perilaku mencuci tangan, memakai masker serta menjaga jaraj (3M) secara disiplin. Selain itu ditemukan juga $36 \%$ dari total responden hanya melakukan dua dari perilaku $3 \mathrm{M}$ dan 23,2\% melakukan 1 dari perilaku 3M. (Laraspati, 2020). Sementara itu, 9,3\% dari responden tidak melakukan kepatuhan $3 \mathrm{M}$ 
sama sekali. Lebih lanjut dari hasil survey ini menunjukkan bahwa secara individual, menjaga perilaku jaga jarak (47\%) lebih rendah daripada memakai masker (71\%) dan mencuci tangan (72\%) (Laraspati, 2020). Rendahnya perilaku menjaga jarak menurut hasil survey ini dikarenakan karena adanya aspek norma sosial yang membuat setiap orang merasa tidak enak hati jika berjauhan atau menjau dengan orang lain. Masyarakat Indonesia sebagai orang timur memiliki budaya kekerabatan yang sangat kuat, yang pada berakibat pada perilaku rasa hormat yang tinggi pada orang lain. Walaupun itu pada kondisi covid-19 seperti saat ini. Hal ini sejalan dengan apa yang dikemukakan oleh Lubis (2013) bahwa orang Indonesia diakui sebagai masyarakat yang bersifat hormat, tenang, dapat dipercaya, baik, royal, ramah pada tamu dan lembut. Ciri masyarakat Indonesia inilah yang kemudian menjadi tantangan dalam melaksanakan berbagai kebijakan yang dikeluarkan oleh pemerintah sebagai upaya mencegah penyebaran virus Covid-19. Dari latarbelakang di atas, perlu kiranya mengkaji relevansi kebijakan publik di era pandemi covid 19 terhadap kesadaran global warga negara.

\section{METODOLOGI}

Tulisan mengidentifikasi ini bertujuan memetakan

untuk menganalisis berbagai wacana akademik dari studi empiris mengenai relevansi antara kebijakan publik di era Pandemi Covid-19 terhadap kesadaran global warga negara.
Untuk menjawab pertanyaan tersebut maka peneliti melakukan analisis terhadap berbagai studi literatur terkait dengan tema yang akan dikaji. Berbagai studi literatur yang digunakan seperti artikel/jurnal nasional dan internasional, buku, sumber internet, gambar dan lainnya menjadi bagian penting dalam sumber data pada tulisan ini. Keseluruhan sumber ini kemudian dianalisis, dibandingkan, serta diinteprestasi untuk menjawab berbagai permasalahan dari penelitian yang dikaji.

\section{HASIL PENELITIAN DAN PEMBAHASAN Kesadaran Global Warga Negara dan Kebijakan Publik Nasional}

Virus Covid-19 merupakan salah satu dari sekian banyak masalah global yang terjadi di berbagai negara di dunia. Dikatakan sebagai masalah global karena satu masalah yang ditimbulkan akan berhubungan bahkan mempengaruhi orang-orang di negara lain. Tanpa disadari tindakan yang dilakukan oleh seseorang akan mempengaruhi orang lain baik di wilayah yang sama maupun diluar negaranya. Ada kecenderungan bahwa masalah global hanya dapat diselesaikan jika adanya sikap saling ketergantungan diantara satu dan lainnya. Hick (2003) yang dikutip dalam (Convery \& Kerr, 2007) mengungkapkan ada empat dimensi yang dapat menjelaskan kaitan antara masalah global dengan orang-orang di negara lain. Keempat dimensi tersebut sebagai berikut:

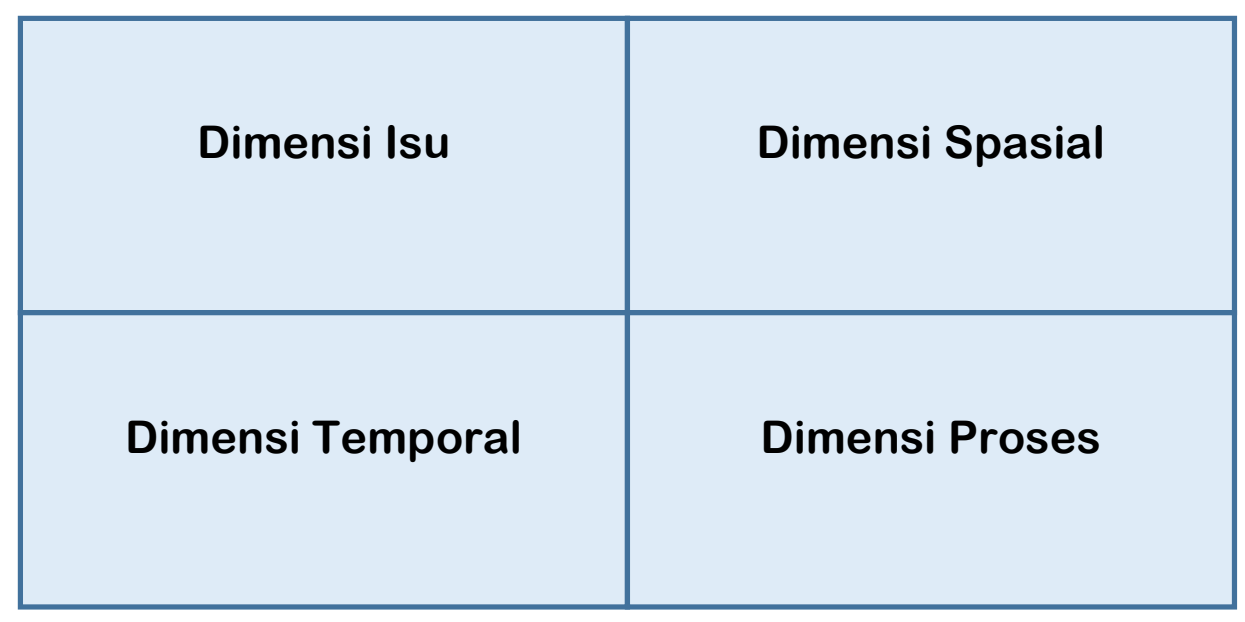

Gambar 1. Empat Dimensi Keterkaitan Masalah Global Terhadap Orang-Orang di Negara Lain

Gambar 1 memperlihatkan empat dalam memahami kaitan antara masalah global dimensi yang dapat djadikan sebagai acuan dengan lingkungan dan orang-orang yang ada 
di negara-negara di dunia menurut Hick (2003) yang dikutip dalam (Convery \& Kerr, 2007). Dimensi pertama adalah isu yakni fokus pada masalah ketidaksetaraan-kesetaraan, ketidakpedulian-kepedulian/keadilan, konflikperdamaian, kerusakan-perawatan serta keterasingan-partisipasi. Bila dilihat dari dimensi ini maka pandemi covid-19 termasuk dalam isu antara ketidakpedulian dan kepedulian/keadilan. Semakin banyak orang yang memiliki kepedulian terhadap masalah kesehatan dunia ini dengan mematuhi berbagai kebijakan yang dikeluarkan oleh pemerintah, maka semakin cepat wabah penyakit ini akan selesai. Dimensi kedua adalah spasial yang menekankan eksplorasi koneksi lokal-global yang berkaitan dengan isu-isu global. Pada dimensi ini kita melihat bagaiamana virus corona yang awalnya berasal dari wilayah Wuhan di China kini menyebar di seluruh negara negara dunia. Pada dimensi ini akhirnya setiap orang menyadari bahwa Pandemi Covid 19 merupakan salah satu dari sekian banyak masalah global yang mempengaruhi kehidupan warga negara di seluruh dunia. Dampaknya mempengaruhi segala aspek kehidupan baik sosial budaya, ekonomi, politik dan aspek lainnya. Hal ini menyadarkan setiap orang betapa pentingnya perilaku yang adil terhadap prinsip-prinsip saling ketergantungan, kesetaraan umat manusia serta tanggung jawab bersama untuk menyelesaikan berbagai masalah global (Carrabain, Keulemans, Gent dan Spitz 2012 dalam Aydin dan Cinkaya, 2018). Karena pada esensinya bahwa kesadaran global adalah cara pandang warga negara terhadap penghormatan dan penghargaan terhadap keanekaragaman serta menyadari keberadaan dunia yang begitu luas dan memahami bagaimana fungsinya.

Dimensi yang ketiga menurut Hick (2003) dalam (Convery \& Kerr, 2007) yakni dimensi temporal. Pada dimensi ini setiap orang harus mampu mengeksplorasi koneksi antara lokal-global dengan isu-isu global. Sebagai bagian dari warga dunia, maka masyarakat Indonesia harus menyadari bahwa penyelesaian covid-19 merupakan tanggung jawab setiap orang. Sikap ini akan menumbuhkan kesadaran yang diikuti rasa peduli dan tanggung jawab dalam menyelesaikannya. Berbagai kebijakan yang dikeluarkan oleh pemerintah pada dasarnya sebagai upaya nasional (negara) dalam menyelesaikan pandemi sebagai masalah global. Untuk memperkuat sikap ini maka setiap orang harus mampu memiliki perspektif global, sehingga tidak melihat dunia secara sempit karena hal ini sangat berhubungan dengan kepentingan, wilayah dan budaya sendiri (Evans dan Reynolds, 2005 dalam Cheng, 2005). Dimensi ini akan lebih sempurna jika diperkuat pada dimensi keempat yakni proses. Pada dimensi ini partisipasi warga negara dengan mengeksplorasi berbagai nilai merupakan tujuan akhir dari kesadaran global warga negara Hick (2003) dalam (Convery \& Kerr, 2007). Berbagai kebijakan yang dikeluarkan untuk menciptakan keadilan, kesejahteraan, rasa aman dapat terwujud jika didukung oleh semua pihak. Maka dari itu, kemampuan untuk melihat dan mendekatkan diri sebagai bagian dari masyarkat dunia adalah langkah kongkrit dalam membangun kesadaran global warga negara (Cogan \& Derricort, 1998).

Pandemi Covid 19 sebagai salah satu masalah global hanya dapat diselesaikan jika setiap orang dapat berpartisipasi dalam menyelesaikannya. Membangun orientasi global, empati dan kepekaan budaya yang berasal dari nilai-nilai kemanusiaan adalah kunci utama dalam menyelesaikan berbagai masalah global (Dill, 2012). Setiap warga negara memiliki tanggung jawab dalam menciptakan kehidupan dunia yang lebih baik dan damai, tanpa konflik, pelanggaran hak asasi manusia, kemiskinan, ketimpangan sosial dan masalah lingkungan (Dower, 2000). Untuk mewujudkan hal tersebut, maka harus ada korelasi yang seimbang antara pemerintah sebagai pembuat kebijakan serta masyarakat sebagai pelaksana aturan yang telah dibuat. Tanggung jawab tanpa aturan tidak akan mungkin dapat berjalan sesuai dengan apa yang diharapkan. Begitu juga aturan tanpa adanya rasa tanggung jawab maka tidak mungkin dapat terlaksana sehingga perlu adanya unsur paksaan. Hubungan diantaranya digambar oleh Easton (dalam Taufiqurrahman, 2014) sebagai the authoritative al-location of values for the whole society atau sebagai pengalokasian nilai-nilai secara paksa kepada seluruh anggota masyarakat.

Jika kita lihat berbagai kebijakan yang dikeluarkan oleh pemerintah terkait penanganan covid-19 seperti dikeluarkannya Peraturan Pemerintah (PP) Nomor 21 Tahun 
2020 tentang Pembatasan Sosial Berskala Besar dalam rangka Percepatan Penanganan Corona Virus Disease 2019 (Covid-19) yang dikeluarkan pada tanggal 31 Maret 2020. Turunan dari PP ini adalah dikeluarkannya Peraturan Menteri Kesehatan No. 9 Tahun 2020 tentang Pedoman pelaksanaan PSBB sebagai upaya Percepatan Penanganan Covid-19. Kebijakan PSBB antara lain: 1) Peliburan sekolah dan tempat kerja; 2) Pembatasan kegiatan keagamaan; 3) Pembatasan kegiatan di tempat/fasilitas umum; 4) Pembatasan kegiatan sosial budaya; 5) Pembatasan moda transportasi; dan 6) Pembatasan kegiatan lainnya terkait aspek pertahanan dan keamanan (Kemlu, 2020). Selain kebijakan tersebut, ada berbagai aturan lainnya terkait penanganan covid-19 baik pada bidang hukum, ekonomi, fiskal, sosial dan kesehatan. Keseluruhan aturan ini diharapkan dapat menekan penularan virus yang lebih banyak di Indonesia.

Kebijakan ini tentu harus didukung dengan kesadaran warga negara terhadap masalah yang sedang terjadi. Hasil penelitian yang dilaksanakan oleh (Harlianty, Widyastuti, Muhkhlis, \& Susanti, 2020) memperlihatkan bagaimana pengaruh antara kesadaran dalam menjaga jarak di lingkungan sosial terhadap penularan virus. Hasil penelitian ini diperkuat dengan kajian yang dilakukan sebelumnya oleh Qazi et al., 2020, dalam (Harlianty, Widyastuti, Muhkhlis, \& Susanti, 2020) yang menyatakan bahwa kesadaran masayarakat terhadap situasi kesehatan saat ini akan mengurangi terjadinya penyebaran virus penyakit. Dalam konteks ini individualisasi sangat diperlukan sebagai upaya adaptasi untuk pengembangan nilai-nilai eksternal terkait pengetahuan, teknologi, dan norma perilaku dalam memenuhi kebutuhan dan karakteristik individu (Cheng, 2005). Implikasi individualisasi dalam pencegahan Covid-19 ini adalah untuk memaksimalkan motivasi, inisiatif dan kreatifitas melalui berbagai langkah-langkah yang mendukung pemeruntah dalam penanganan virus. Sehingga ada upaya mengaktulisasikan diri, tanggung jawab mandiri, serta memulainya dari diri sendiri (Cheng, 2005). Jika memahami apa yang dikemukakan oleh Cheng (2005) lalu dikaitkan dengan kesadaran global dan kebijakan publik terkait penanganan virus Covid 19 maka kita dapat melihat gambar di bawah ini :

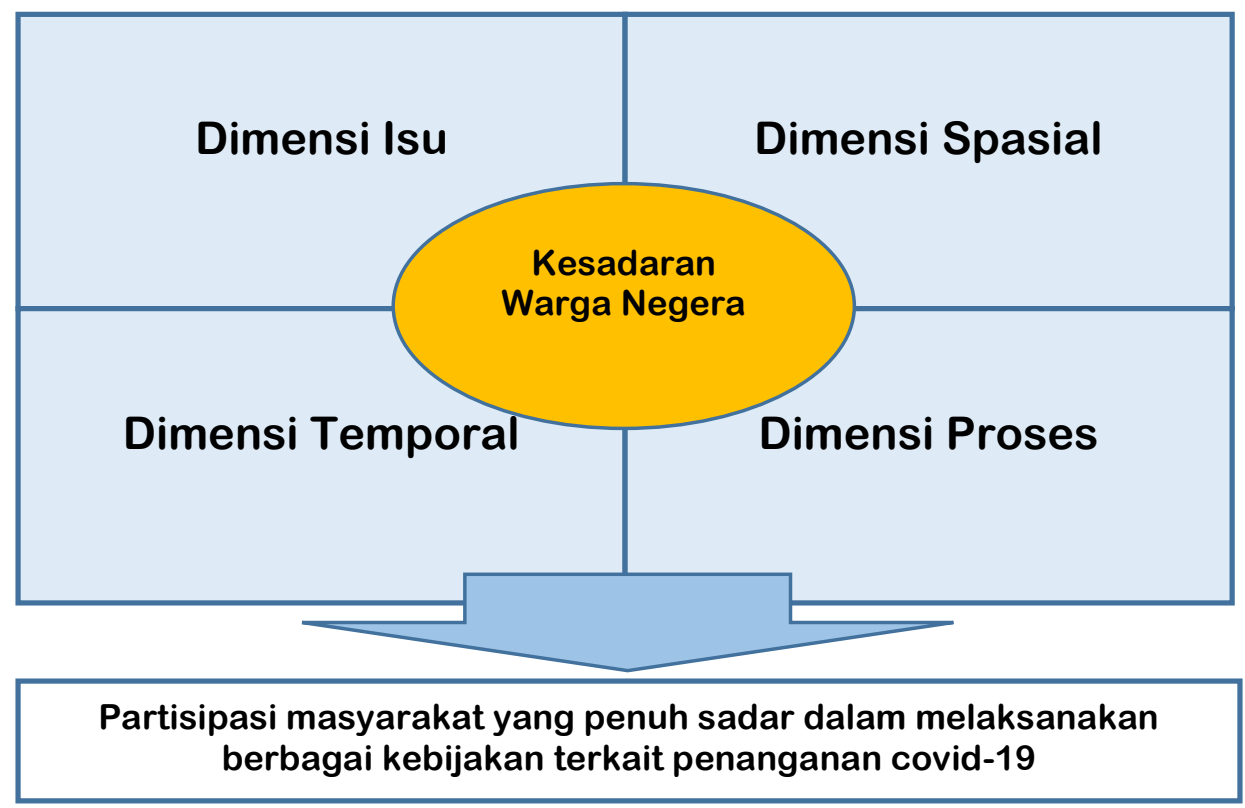

Gambar 2. Hubungan Antara 4 Dimensi dalam Membangun Kesadaran Warga Negara Terhadap Partisipasi Dalam Melaksanakan Kebijakan Publik

Gambar 2 memperlihatkan hubungan simultan antara empat dimensi dalam membangun kesadaran warga negara terhadap partisipasi dalam melaksanakan berbagai kebijakan publik. Jika di analogikan maka dapat dikatakan bahwa warga negara yang 
memahami tentang ketidakadilan, konflik, perdamaian, partisipasi dan sikap peduli maka dia akan mengkaitkan berbagai isu tersebut baik dalam konteks lokal, nasional maupun global. Warga negara seperti ini akan memahami bahwa globalisasi mengacu pada transefer, adaptasi dan pengembangan nilainilai, pengetahuan, teknologi dan norma-norma di berbagai negara dan masyarakat di berbagai belahan dunia (Cheng, 2005). Warga negara seperti ini akan terus belajar tentang keadilan sosial, penghormatan terhadap demokrasi dan keanekaragaman serta berupaya berkolaborasi dalam menyelesaikannya Convery \& Kerr, 2007; Bell, 2016).

Selanjutnya ketika setiap orang telah mampu mengkoneksikan antara isu global dengan kehidupan lokal dan nasionalnya, maka dia harus mampu mengeksplorasi hubungan antara masa lalu, sekaran dan masa depan. Dalam konteks ini ada berbagai nilai-nilai yang diyakini dapat menjadi pegangan dan bersikap dan bertindak. Warga negara tidak harus begitu terikat dengan masa sekarang sehingga melupakan masa lalu dan masa yang akan datang (Budimansyah dan Suryadi, 2008). Hal ini berarti berbagai kebijakan yang dikeluarkan oleh pemerintah harus dijalakan dengan memegang teguh nilai-nilai bangsa Indonesia yang sudah ada jauh sebelum bangsa Indonesia merdeka. Misalnya saja nilai kejuangan, pantang menyerah, gotong royong, mandiri, kesetiakawanan sosial serta religius. Nilai-nilai ini akan menjadi spirit dalam membangun kesadaran warga negara yang secara konsisten menjalankan berbagai kebijakan terkait penanangan covid-19 di Indonesia. Hal ini sejalan dengan teori pohon yang dikembangkan oleh Cheng (2005) yang mengasumsikan bahwa pertumbuhan pohon seperti proses pembinaan pengetahuan di tingkat lokal yang berakar pada nilai-nilai dan tradisi lokal yang digunakan untuk membangun orientasi global warga negara.

\section{SIMPULAN}

Pandemi Covid-19 adalah salah satu dari sekian banyak masalah global yang mempengaruhi kehidupan warga negara. Berbagai kebijakan dikeluarkan oleh pemerintah Indonesia dalam penanangannya. Akan tetapi berbagai fakta memperlihatkan bahwa kebijakan yang dikeluarkan tidak mampu membangun sebagian kesadaran warga negara terhadap virus covid-19. Berbagai informasi yang diperoleh baik dari media cetak maupun online, hasil penelitian dan sumber lainnya menunjukkan rendahnya angka kepatuhan masyarakat dalam menajalan protokol kesehatan yakni menjaga jarak, mencuci tangan dan memakai masker (3M) sebagai upaya pencegahan penularan virus covid. Hal ini menyebabkan angka kematian dan kasus positif terhadap virus semakin hari semakin bertambah.

Kebijakan publik dan kesadaran warga negara adalah dua hal yang tidak dapat dipisahkan. Kebijakan yang harus ditaati tanpa rasa sadar tidak akan memberi efek jera bagi masyarakat. Untuk itu ada empat dimensi yang harus dipahami oleh warga negara agar mampu melaksanakan kebijakan secara utuh dalam pencegahan dan penangan covid-19. Empat dimensi tersebut adalah dimensi isu, yakni pengetahuan warga negara terhadap berbagai masalah global seperti covid-19. Kedua dimensi spasial, yakni bagaimana warga negara mampu menghubungkan antara masalah global dengan kehidupan lokal dan nasional negaranya. Ketiga dimensi temporal, yakni kemampun warga negara mengeksplorasi hubungan antara masa lalu, sekarang dan masa depan. Warga negara harus meyakini bahwa bangsa Indonesia memiliki berbagai nilai-nilai zaman dahulu yang dapat dijadikan sebagai pegangan dalam menyelesaiakan berbagai masalah termasuk Covid-19. Nilai tersebut yakni ketangguhan, solidaritas, gotong royong, mandiri, religius, dan sebagainya. Keempat adalah dimensi proses sebagai muara akhir dari upaya warga negara untuk berpartisipasi dalam menjalanakan berbagai kebijakan yang dikeluarkan oleh pemerintah terkait penanganan covid-19. Jika keseluruhan nilai ini dapat dilaksanakan secara utuh, maka bangsa Indonesia akan mampu keluar dari berbagai masalah termasuk pandemi Covid-19.

\section{DAFTAR PUSTAKA}

Adlin, A., \& Yusri, A. (2020). Penegakan Hukum Pemerintahan : Kekuasaan Walikota Pekanbaru Memberlakukan Beleidsregels Guna Memutus Penyebaran Virus Covid- 19 Di Kota Pekanbaru. Jurnal Ilmiah Muqoddimah, 4(2). doi: http://dx.doi.org/10.31604/jim.v4i2.2020.7 $1-81$

Aydin, H., \& Cinkaya, M. (2018). Global citizenship education and diversity (GCEDS): A 
measure of students' attitudes related to social studies program in higher education. Journal for Multicultural Education. doi:10.1108/JME-05-2017-0030

Bell, K. (2017). Educating Global Citizens Through International Partnerships for Social Justice. Innovations in Higher Education Teaching and Learning, 8, 19-36. doi:10.1108/S2055-364120160000008002

Budimansyah, D., \& Suryadi, K. (2008). PKn dan Masyarakat Multikultural. Bandung: Program Studi Pendidikan Kewarganegaraan SPS UPI

Convery, A., \& Kerr, K. (2007). Acting Locally to Have Global Impact: Citizenship Education in Theory and Practice in England. Journal Citizenship, Social And Economics Education, 7(3), 189-200. doi:1357-4019/00/02 0189-12

Cheng, Y. C. (2005). New Paradigm for Reengineering Education: Globalization, Localization and Individualization. Netherlands: Springer.

Cogan, J., \& Derricott, R. (1998). Citizenship for the 21st Century; An International Perspective on Education,. London: Kogan Page.

Dill, J. S. (2012). The Moral Education of Global Citizens. Journal Soc, 49, 541-546. doi:10.1007/s12115-012-9599-8

Dower, N. (2000). The idea of global citizenship-A sympathetic assessment. Journal Global Society, 14(4), 553-567.

Ebrahim, S. H., Ahmad, Q. A., Gozzer, E., Schlagenhauf, P., \& Memish, Z. A. (2020). Covid-19 and community mitigation strategies in a pandemic. BMJ, m1066. doi:http://dx.doi.org/10.1136/bmj.m1066.

Harlianty , R. A., Widyastuti, T., Muhkhlis, H., \& Susanti, S. (2020, July). Study on Awareness of Covid-19, Anxiety and Compliance on Social Distancing in Indonesia During Coronavirus Disease 2019 (COVID-19) Pandemic. ResearchGate. doi:DOI: 10.21203/rs.3.rs-44598/v1
Kemlu . (2020, April 22). Kebijakan Pemerintah Republik Indonesia Terkait Wabah Covid-19. Retrieved from Kemlu.go.id: https://kemlu.go.id/brussels/id/news/6349 /kebijakan-pemerintah-republik-indonesiaterkait-wabah-covid-19

Kompas. (2020, July 29). Rendahnya Kesadaran Masyarakat akan Bahaya Covid-19. Retrieved from Kompas.id: https://kompas.id/baca/video/2020/07/29 /rendahnya-kesadaran-masyarakat-akanbahaya-covid-19/

Kunjana. (2020). Baru 2 Provinsi dan 22 Kabupaten/Kota yang Terapkan PSBB. Retrieved from investor.id: https://investor.id/national/baru-2provinsi-dan-22-kabupatenkota-yangterapkan-psbb

Peraturan Pemerintah (PP) Nomor 21 Tahun 2020 tentang Pembatasan Sosial Berskala Besar (PSBB).

Laraspati, A. (2020, November 20). Hasil Survei Tunjukkan Kesadaran Masyarakat soal Pencegahan COVID-19. Retrieved from detik.com: https://news.detik.com/berita/d5243808/hasil-survei-tunjukkan-kesadaranmasyarakat-soal-pencegahan-covid-19

Lubis, M. (2013). Manusia Indonesia. Jakarta: Yayasan Pusataka Obor Indonesia.

Satgas Penanganan Covid. (2020, Desember 28). Jumlah Kasus Covid 19 di Inonesia. Retrieved from covid19.go.id: https://covid19.go.id/

Singh, A. K., Agrawal, B., Sharma, A., \& Sharma, P. (2020). COVID-19: Assessment of knowledge and awareness in Indian society. Willey Public Health Emergency Collection. doi: $10.1002 /$ pa.2354

Taufiqurokhman. (2014). Kebijakan Publik: Pendelegasian Tanggung Jawab Negara Kepada Presiden Selaku Penyelenggara Pemerintah. Jakarta: Fakultas Ilmu Sosial dan Politik Universitas Moestopo Beragama Press.

https://www.worldometers.info/coronavirus. Covid-19 Coronavirus Pandemic. Diakses pada tanggal 25 Desember 2020 